\title{
Successful test dry heat oven sterilizer on dental instruments sterilization in X Hospital
}

\author{
Arrahmi Amir*, Warta Dewi*, Riana Wardani** \\ *Department of Oral Biology Faculty Of Dentistry Universitas Padjadjaran \\ **Department of Dental Public Health Faculty of Dentistry Universitas Padjadjaran
}

\begin{abstract}
Introduction: Instruments used for dental examinations and treatment often come into contact with fluids and soft tissues found in the oral cavity. The contact while the dental treatment procedures can cause contaminated and potentially mediates the displacement of microorganisms from the mouth of the patient to the operator or to other patients. Sterilization is the most effective process for the decontamination of reusable equipment. The objective of this study was testing the success of dry heat oven sterilizer to dental instruments sterilization in X Hospital. Methods: This study used descriptive method. Data was obtained by bacteriological examination, with a random sampling technique and obtained a sample of five instruments. Results: The results show there is a growing colony of bacteria in each sample after examination materials were incubated at $37{ }^{\circ} \mathrm{C}$ for $18-24$ hours. Conclusion: The conclusions of this study are dry heat oven sterilizer not belong to the success criteria for dental instrument sterilization process in X Hospital.
\end{abstract}

Keywords: Dry heat oven, instrument, sterilization.

\section{INTRODUCTION}

Dentists are health care workers who are prone to cross-infection of patients they care for due to direct contact with blood and microorganisms in the oral cavity of patients. Instruments used during dental examination and treatment comes in contact with fluids and soft tissue of the oral cavity can cause the tool to become contaminated and potentially mediate the transfer of microorganisms from the patient's mouth to the operator or to other patients. Sterilization is the most effective process for decontamination for reusable purposes.

Sterilization is a chemical and physical process that aims to destroy all life forms of microorganisms Including spores. There are two types of sterilizers that are most commonly used throughout the world items, namely autoclaves and dry heat ovens. Some failures that occur in a sterilizer are the caused by mechanical damage..$^{6-7}$

Research conducted on dental clinics in the United Kingdom, proved that $2 \%$ of the 401 samples used autoclave failed to sterilize the dental instruments. This proves that it is necessary to test autoclaves and other sterilizers used in dentistry before using in daily practice. ${ }^{8}$ Inadequate sterilization may increase the risk of pathogenic microorganisms spread patients undergoing treatment. ${ }^{2}$ There are two

Corresponding author: Warta Dewi, Department of Oral Biology, Faculty of Dentistry Universitas Padjadjaran, Indonesia. Jalan Sekeloa Selatan I, Bandung, West Java, Indonesia, 40132; Phone: +6222-2504985/2532805 
types of infections caused by the activity of microorganisms, ie endogenous and exogenous. Endogenous infections caused by normal flora or microorganisms that are naturally present in the body, that has the potential to cause a disease. opportunistic pathogenic microorganisms can cause disease when it travels and is able to multiply in the deeper body tissues. The microorganisms will release enzymes and toxins that can cause diseases that will irritate and harm the body.

Exogenous infection is caused by external microorganisms in the body invades, but have come from outside the body through the cross infection intermediariesprocess. ${ }^{5}$ Tthe transmission of disease from one person to another through a medium that is generally perantara. ${ }^{9}$ Prevention of cross infection is a serious problem that is very important in oral medicine. ${ }^{10}$ Sterilization of instruments that are to be reused is one of the efforts that can be done to prevent crossinfection oral medicine. ${ }^{11}$

\section{METHODS}

This research is a descriptive research. The object of this research is the dry heat sterilizer oven used byin the sterilization department in hospital $X$. Research is done in September 2012. The research was conducted by observing the growth of bacterial colony on blood based agar. The blood based agar acts as plates as the culture medium for of this observation., Material for research is taken from instruments that was sterile from the dry heal oven.

linstrument is considered sterile when there is no colony of bacteria formed on the blood based agar. Instruments included in this study is the basic instruments inof dentistry such as glass mouth mirror, explorer, excavators, probes and dental forceps. The tools used in the study was spritus lampBunsen burner, test tubes, test tube rack, pipettes, flask, petri dish, sforceps, incubators, glass slide, microscope and colony counter. Materials used in the study was basic dental instruments which has been sterilized, bulyon solution, alcohol, blood based agar as a culture medium. Sterilized instruments are placed $10 \mathrm{ml}$ of sterilizing solution, shaken for 1 minute in the hope of the bacteria from the instrument will transfer to the solution. Solution was sealed and taken to the laboratory for examination. Materials is placed in the blood based agar as 0.1 $\mathrm{ml}$ culture medium by the cutting a line on the agar with the instrument. Planting of materia is done with three repetitions to get the average value and the results are accurate.

For control of positive bacterial colonization growth, material sample is taken from instrument that has been used for dental examination or treatment to the patient but has not been sterilized. blood based agar with materials that has been planted is incubated at $37^{\circ} \mathrm{C}$ temperature for 18-24 hours the facultative anaerobic and the growth of colonization is observed. The presence of bacterial growth on culture media indicates that the sterilization is not perfect The number of bacterial colonies is counted using the colony counter on each blood based agar to colonies of bacteria growth on blood agar medium plates.

In this study, a negative control was made. Material $0.1 \mathrm{ml}$ of bulyon sterile solution was planted on the blood based agar as a negative control experiment, incubated for 18-24 hours at a temperature of $37^{\circ} \mathrm{C}$ just as the other two blood based agar. The results of this is negative growth of bacteria colony. With this, it can be said that the bulyon solution and the blood based agar is sterile.

\section{RESULTS}

After materials planted in blood based agar in LAD and incubated for 18-24 hours at a temperature of $37^{\circ} \mathrm{C}$, visible growth of bacterial colonies is observed.

Table 1. Examination Bacteriology Instruments Dental Hospital X

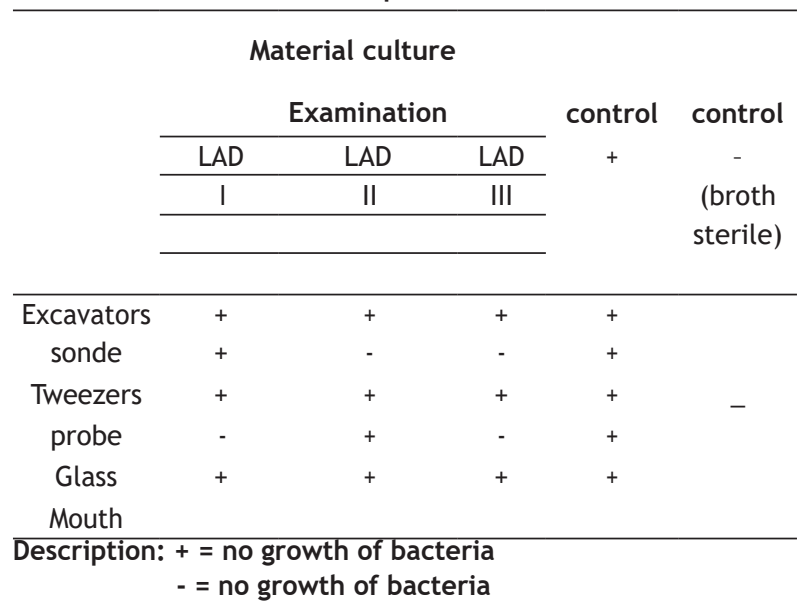


Based on Table 1. The bacterial colony growth in dental hospital $X$ indicates variant results including bacterial growth from, the LAD LAD II and III of the instrument explorer, and LAD I and LAD III of the probe instruments that have not been sterilized showed positive bacterial growth, while the negative control of sterile solution showed no bacterial growth.

Table 2. Calculation of Number of colonies The bacteria that are in LAD

\begin{tabular}{cccc}
\multicolumn{4}{c}{ that are in LAD } \\
\hline \multicolumn{4}{c}{ Examination Material culture } \\
\hline & LAD I & LAD II & LAD III \\
\hline Excavators & $\infty$ & 3 & $\infty$ \\
sonde & 5 & - & - \\
Tweezers & 1 & 1 & 3 \\
Probe & - & 2 & - \\
glass mouth & 2 & 4 & 2 \\
\hline Specification: $\infty$ & $=$ Infinity & &
\end{tabular}

Based on Table 2, the calculation for the number of colonies of bacteria contained in the LAD shows infinite number bacterial growth in LAD I and LAD III of instruments excavators, while three colonies were found in LAD II. In LAD II and III no bacterial growth was detected of the explorer instrument, but at the LAD I five colonies were fount.

There is growth of bacteria colonies on the third LAD of dental forceps instrument, a total of 1 colony on LAD I and LAD II, as well as 3 colonies on LAD III. On the probe instrument did not reveal any bacterial growth in the LAD I and LAD III, but 2 colonies were found in LAD II. Two colonies of bacteria found two colonies on LAD I and LAD III for mouth mirror instrument, while four colonies was found on LAD II.

Tabel 3. Hasil Pemeriksaan Mikroskopis dari Koloni-Koloni pada LAD

\begin{tabular}{|c|c|c|c|c|c|c|}
\hline & $\begin{array}{c}\text { Staphylo } \\
\text { coccui }\end{array}$ & $\begin{array}{l}\text { Strepto } \\
\text { coccui }\end{array}$ & $\begin{array}{c}\text { Cocci } \\
\text { Gram } \\
\text { negatif }\end{array}$ & $\begin{array}{c}\text { rod } \\
\text { Gram } \\
\text { positif }\end{array}$ & $\begin{array}{c}\text { rod } \\
\text { Gram } \\
\text { negatif }\end{array}$ & Spore \\
\hline Excavators & + & - & - & + & + & + \\
\hline Sonde & + & - & + & - & - & - \\
\hline Tweezers & + & + & - & - & - & - \\
\hline Probe & + & - & - & + & + & - \\
\hline $\begin{array}{l}\text { glass } \\
\text { mouth }\end{array}$ & + & + & - & + & + & + \\
\hline
\end{tabular}

From the table above it was found that the colonies contained in the LAD, there are more than one species of bacteria found on the instrument.
Based on Table 3, the results of microscopic examination of excavators show that the presence of Staphylococcus bacteria, Gram-positive rods with , spore and Gram-negative rods. On the explorer instrument, found Staphylococcus and Gram-negative cocci.

Staphylococcus and Streptococcus was found on the dental forceps. On probe Staphylococcus bacteria, Gram-positive rods and Gram-negative rods was found. Bacteria found in the smouth mirror instruments consist of Staphylococcus, Streptococcus, gram-positive rods and Gramnegative rods. Based on Table 3, spore-producing bacteria is only found on examination materials such as excavators and mouth mirrors, and not present on the explorer, dental forceps, and the probe.

\section{DISCUSSION}

Based on these results, there are several colonies of bacteria found in the examination material from several dental instruments dentistry in hospital RS X. This is in accordancethis is proven with in Table 4.1 which shows the different bacterial colonies at the growth in he blood based agarof bacteria on the results of the examination. The presence of multi bacterial growth in the LAD of dental instruments dentistry that has already been is sterilized by using a dry heat oven at hospital RS $X$ can be caused by a sterilizer that works less wellineffectively, or already even broken,, errors in the methods appliedhandling the sterilizing machine, wrong method of the cleaning the dental of instruments less clean of debris organic, and error in packaging or storage of the instrument. ${ }^{5}$

Some of the failures that occurroccurs due to the mechanical damage of the ed in the sterilizer due to damage mekanis. ${ }^{6-7}$ Therefore, based on this the sterilizer should be reviewed serviced regularly. When serviced regularly, with the result $\mathrm{s}$ of its work will be according to the guidelines of bacteriological tests tersebut. Instrument that was taken as material samples in this study is the mouth mirror, explorer, dental forceps, excavator, and probe due to their frequent use in every dental procedure and the most in contact with infectious areas. appliance factory that made the examination materials in this study consisted of a mouth mirror, sonde, tweezers, excavators, 
andbelonging probe instrument group semicritical and most frequently used and exposed to materials that are infectious.

Decontamination of these instruments can be done by means of sterilization and disinfecting by ion using a high a disinfectant level tinggi. ${ }^{12}$ Sterilization of instrument at HospitalRS $X$ sterilization to the is by instrument using a dry heat oven. Sterilizer is recommended for linstrument recommended for sterilization process are only instrument that is heat resistant and made of metal so that it is not prone to rust because it does not cause karat. ${ }^{13}$ Preferably thThee sterilization process is monitoringred through the indicator is advised, ,especially biological indicators biologis. ${ }^{5}$ The absence of spores on If biological indicator indicates the absence of spores, indicatesmeaning there arewere no bacteria present. This is because the bacteria resistance is lower than that of sporespora. ${ }^{14}$ The results in Table 3 shows there is $\mathrm{w}$ still found spore producing bacteria on excavators and mouth mirror. the instrument glass excavators and mouth. Bacteriaium produces er spores which is The rod is a Gram-positive rod bacterium.

Bbased on Table 3, Staphylococcus is aa bacterium thatseluruhbahan found on any examination materials. Streptococcus is only found in two instruments. The Gram-positive bacteria and negative rods are found in materials excavators, permeriksaan of instruments, probes, and a mouth mirror. Staphylococcus is a Grampositive bacteria that have formations resembling clusters of grapes circuit. One of the factors that cause Staphylococcus bacteria most commonly found because it is easy to grow in a variety of media and temperature factors. In this study, the incubation temperature used was $37^{\circ} \mathrm{C}$, at which the temperature of Staphylococcus bacteria grow most cepatrapid. ${ }^{15}$

Excavator on the instrument mMost commonly found bacterial colonies in an infinite number are found on excavators. This is because these instruments are used longer and often necrotic tissue in contact with the necrotic tissue in teeth, soft tissue, blood, and saliva, so the initial cleaning or brushing before sterilized instruments need to be done right.

Based on these results, it turns out dry heat sterilizer oven sterilization does not meet the sterilization success criteria. It is seen from the results of bacteriological examination onf examination materials sterilized instruments of examination materials which still have a growth of bacterial colonies and the discovery of bacteria spores. This fact is not in accordance with the understanding that sterilization as a process that kills or eliminates microorganisms and spores shape contained in the form of aed in an objekobjects. ${ }^{14}$

Bacteria cContaminants bacteria such as Staphylococcus and Gram-negative rods are found on the basis of $c$ dental instruments after sterilization, so we need to be careful because both of these bacteria often cause cross infection and nosocomial infections. In addition, also found bersporadic Gram-positive rods that were also found and it can impede wound healing and indicates that the sterilization process was not successful.

universal Universal precautions, Aseptic aseptic technique, and the sterilization process is a necessary condition that must be done correctly in dentistry, so as to minimize instruments contamination of instruments by microorganisms and prevent the risk of cross infection silang. ${ }^{14}$

\section{CONCLUSION}

Based on the results of research and discussion, it can be concluded that the dry heat sterilizer oven sterilizing tool has not met the success criteria against dental instrument sterilization at the hospital $X$. This is evident shown based from on the results of the study, they found the bacteria were still found on the material examination of dental instruments that have been sterilized using dry heat oven.

\section{REFERENCES}

1. Martin MV, Fulford MR, Preston AJ. Infection Control for The Dental Team. London: Quintessence Publishing. 2009. p. 2-36.

2. Johnson R. Instrument Management: Cleaning and Sterilization in The Dental Setting. Dental Nursing 2010;6(9):504-509.

3. Griffiths, R. Doing It Right! New Guidance on 'Decontamination in Primary Dental Care Practice'. Dental Health London 2010;49(1):18-19. 
4. Fox C. Evidence Summary: What 'Cost of Illness' Evidence Is There about Cross-Infection Related Infections in Dental Practice?. British Dental Journal 2010;209(2):87-88.

5. Miller $\mathrm{CH}$, Palenik CJ. Infection Control and Management of Hazardous Materials fot the Dental Team. 4th edition. Philadelphia: Elsevier's Health Sciences Right Department. 2010. p. 110-159, 191-245.

6. Palenik CJ. Miller $\mathrm{CH}$. Using The Office Steam Autoclave. Dental Asepsis Rev 1999;(20): 1-2.

7. Skaug $N$, Lingaas $E$, Nielsen $O$, Palenik, CJ. Biological Monitoring of Sterilizers and Sterilization Failures in Norwegian Dental Offices in 1985 and 1996. Acta Odontol Scand 1999;(57):175-180. Oslo. ISSN 0001- 6357

8. Burke FJTWA. Coulter SW, Cheung CJ. Palenik. Autoclave Performance and Practitioner Knowledge of Autoclave Use: A Survey of Selected UK Practices. Quintessence International 1998;(29): 231-238.

9. Darmadi. Infeksi nosokomial: Problematika dan Pengendaliannya. Jakarta: Salemba
Medika. 2008. p. 15-27.

10. Viana ACD, Gonzalez BM, Buono VTL, Bahia, MGA. Influence Of Sterilization On Mechanical Properties And Fatigue Resistance Of NickelTitanium Rotary Endodontic Instruments. International Endodontic Journal 2006;(39): 709-715.

11. Venkatasubramanian R, Jayanthi, Das UM, Bhatnagar S. Comparison Of The Effectiveness Of Sterilizing Endodontic Files By 4 Different Methods: An In Vitro Study. J Indian SOC Pedodontia Prevent Dent 2010;(28): 2-5.

12. Bird DL, Robinson DS. Modern Dental Assisting. 8th edition. Philadelphia: Elsevier's Health Sciences Right Department. 2005.

13. Cohen A Dental Sterilization Solutions. Dental Assessment. Objet Geometries Ltd. 2010.

14. Samaranayake LP, Essential Microbiology for Dentistry: Ed.3rd. London: Churchill Livingstone. 2006. p. 118-136, 309-324.

15. Brooks GF, Butel JS, Ornston LN. Jawet, Melnik Adelberg. Mikrobiologi Kedokteran. 20 Ed. Jakarta: EGC. 1996. p. 190-232. 